\title{
Editorial
}

\section{New Activities of the Nuclear Pore Complexes}

\author{
Richard W. Wong $1,2,3$ (D) \\ 1 WPI-Nano Life Science Institute, Kanazawa University, Kanazawa 920-1192, Japan; \\ rwong@staff.kanazawa-u.ac.jp \\ 2 Graduate School of Frontier Science Initiative, Kanazawa University, Kanazawa 920-1192, Japan \\ 3 Cell-Bionomics Research Unit, Institute for Frontier Science Initiative, Kanazawa University, \\ Kanazawa 920-1192, Japan
}

\begin{abstract}
Nuclear pore complexes (NPCs) at the surface of nuclear membranes play a critical role in regulating the transport of both small molecules and macromolecules between the cell nucleus and cytoplasm via their multilayered spiderweb-like central channel. During mitosis, nuclear envelope breakdown leads to the rapid disintegration of NPCs, allowing some NPC proteins to play crucial roles in the kinetochore structure, spindle bipolarity, and centrosome homeostasis. The aberrant functioning of nucleoporins (Nups) and NPCs has been associated with autoimmune diseases, viral infections, neurological diseases, cardiomyopathies, and cancers, especially leukemia. This Special Issue highlights several new contributions to the understanding of NPC proteostasis.
\end{abstract}

Keywords: nuclear pore complex; nanomedicine; liquid-liquid phase separation; biomacromolecule; HS-AFM; nucleoporin; nanoimaging

Citation: Wong, R.W. New Activities of the Nuclear Pore Complexes. Cells 2021, 10, 2123. https://doi.org/ $10.3390 /$ cells 10082123

Received: 16 August 2021

Accepted: 17 August 2021

Published: 18 August 2021

Publisher's Note: MDPI stays neutral with regard to jurisdictional claims in published maps and institutional affiliations.

Copyright: (C) 2021 by the author. Licensee MDPI, Basel, Switzerland. This article is an open access article distributed under the terms and conditions of the Creative Commons Attribution (CC BY) license (https:// creativecommons.org/licenses/by/ $4.0 /)$.
The nuclear pore complex (NPC) [1-3] is a nanoscale gatekeeper with a central, selective, cobweb-like barrier composed mainly of nucleoporins (Nups), which comprise intrinsically disordered (non-structured) regions (IDRs) with phenylalanine-glycine (FG) motifs (FG-Nups) [4-8]. A fully assembled NPC in vertebrates contains multiple copies of approximately 30 different Nups and has an estimated molecular mass of $120 \mathrm{MDa}$ [9]. Despite our knowledge of the NPC structure, the molecular mechanisms underlying its regulatory roles remain to be understood $[1,3]$. Using high-speed atomic force microscopy (HS-AFM), we showed that FG-Nups are in a liquid-liquid phase separated (LLPS) state $[10,11]$ in which rapid and transient intermediates of FG filaments and sometimes co-exist with a central plug during conformational changes in cancer cells and organoids [12]. The real-time HS-AFM images also suggested that the NPC central channel has a moist cobweb-like structure [13]. Our laboratory also explored additional functions of NPCs beyond nuclear transport [14,15] and found that nucleoporins Rae1 [16,17], Tpr [18-20], Nup358/RanBP2 [21], Nup62 [22], Nup58 [23], and Nup88 [24] play critical roles in maintaining spindle bipolarity, centrosome and mid-body homeostasis during cell division $[25,26]$. For instance, we provided several lines of evidence that the phosphorylation of the cohesin subunit, SMC1, stimulates binding to mitotic Rae1 [27,28], a phenomenon recently confirmed by others to form part of a mechanism of antimitotic catastrophe in early tumorigenesis [29]. Indeed, Rae1 is highly overexpressed in colon cancer [30]. We and others also showed NPCs and nuclear transport proteins play critical roles in various cancers [31-34], especially leukemia [35,36]. A decade ago, we showed that the nuclear pore protein, Tpr, involved in autophagy [37], which affects ependymoma [38] and myogenic differentiation [39] in mammalian cells. Recently, two studies further proved that NPCs are targeted for vacuolar degradation through selective autophagy [40,41]. On the basis of our above contributions to the understanding of NPC structure and function, we were invited to organize a Special Issue in Cells entitled "Nuclear Pore Complex in Nanomedicine". 
In this Special Issue, Yang et al. explore the functions of Nup62-like (Nup62l) mRNA in the pharyngeal arches (PA) during zebrafish development [42]. They demonstrate that CRISPR/Cas9-mediated gene knockout of Nup62l leads to defective PA characterized by a thinned and shortened pharyngeal region and a significant loss of pharyngeal cartilage [42]. They also show that the aberrant activation of a series of apoptotic pathways in Nup621mutants is closely associated with the inactivation of Wnt/ $\beta$-catenin signaling [42].

The contribution by Okazaki et al. shows that Nup62 depletion induces cell cycle arrest before meiosis without CDK1 activation in Drosophila cells [42]. The ectopic overexpression of $\mathrm{CycB}$, but not constitutively active $\mathrm{CDK} 1$, results in partial rescue of the cell cycle. Protein complexes containing $\mathrm{CycB}, \mathrm{Emb}$, and Nup62 are also identified in premeiotic spermatocytes. $\mathrm{CycB}$, which temporally enters the nucleus, associates with $\mathrm{Emb}$, and the complex is transported back through the central channel to the cytoplasm, where it interacts with the Nup62 complex [43].

Emerging evidence suggests a crucial role for interactions between HIV-1 proteins and host nucleoporins $[44,45]$ in the import of the pre-integration complex into the nucleus and export of viral RNAs into the cytoplasm during viral replication [46]. Remarkably, HIV destabilizes the host nuclear pore complex to enter into and exit through the nucleus. Several papers suggest a crucial role of interactions between HIV-1 proteins and host nucleoporins that underlie the import of the pre-integration complex into the nucleus and export of viral RNAs into the cytoplasm during viral replication [44-46]. Shukla and Chauhan highlight the recent progress and challenges in developing a more effective antiviral arsenal by exploring critical host-HIV interactions involving NPCs and nucleoporins [46].

The last contribution examines the pathways used by SARS-CoV-2 and other viruses to invade the host nucleocytoplasmic transport system. Sajidah et al. discuss the viral and host factors involved in the nuclear import and export of viral components [47]. The novel human betacoronavirus SARS-CoV-2 has triggered an unprecedented pandemic in the 21st century, and several studies have revealed interactions between SARS-CoV-2 viral proteins and host nucleoporins $[48,49]$. As nucleocytoplasmic shuttling is crucial for the replication of many viruses, Sajidah et al. also review several drugs that target the host nuclear transport machinery and discuss their feasibility as antiviral treatments [47]. How viral components enter or hijack the NPC undoubtedly requires further exploration.

Unlike most studies of NPCs, which use yeast or mammalian cells as model systems, the above contributions to this short Special Issue investigate NPC protein Nup62 in zebrafish and Drosophila systems. In addition, several interesting NPC-related studies have also recently been published in Cells. For example, extracellular vesicles (EVs) derived from cancer cells contain proteins and nucleic acids responsible for pro-tumorigenic and pro-metastatic effects. What happens to EV cargo molecules once inside the target cells? Does nuclear delivery of the endocytosed EV components impair intercellular crosstalk? Are there any other pathways besides nuclear pores implicated in the nuclear translocation of EV-derived cargo? [50]. Interaction between endocytosed EVs and NPCs may provide another target for therapeutic intervention using nanomedicine in the near future.

Finally, the direct visualization of NPCs and DNA-histone interactions is the key to understanding epigenetic regulation and gene expression [51]. NPCs and nuclear envelope proteins are involved in modulating heterochromatin formation and functions in fission yeast [52] and regulating chromatin state [53]. The condensation and compartmentalization of membraneless biomacromolecules such as NPCs and their FG-Nups are dependent on phase separation. Analytical tools using microfluidic devices, nanoimaging systems with high spatiotemporal resolution such as HS-AFM [54], and proteomics, together with artificial intelligence methods (e.g., Alphafold2) $[55,56]$ that combine them, are expected to play an important role in studying the NPC-LLPS-mediated control of chromatin structure [57]. An understanding of this crucial area of NPC function will be required for a definitive proof of the gene gating hypothesis proposed by Gunter Blobel [58]. 
Funding: This work was supported by the Japan Society for the Promotion of Science (JSPS) KAKENHI Grant Numbers 21K19043 and the Kobayashi International Scholarship Foundation, and the Shimadzu Science Foundation (to R.W.W.).

Acknowledgments: The author thanks to all the current and former members of the Richard Wong laboratory.

Conflicts of Interest: The author declares no conflict of interest.

\section{References}

1. Fernandez-Martinez, J.; Rout, M.P. One Ring to Rule them All? Structural and Functional Diversity in the Nuclear Pore Complex. Trends Biochem. Sci. 2021, 46, 595-607. [CrossRef] [PubMed]

2. Cho, U.H.; Hetzer, M.W. Nuclear Periphery Takes Center Stage: The Role of Nuclear Pore Complexes in Cell Identity and Aging. Neuron 2020, 106, 899-911. [CrossRef] [PubMed]

3. Lin, D.H.; Hoelz, A. The Structure of the Nuclear Pore Complex (An Update). Annu. Rev. Biochem. 2019, 88, 725-783. [CrossRef] [PubMed]

4. Wong, R.W. Nuclear Pore Complex: From Structural View to Chemical Tools. Chem. Biol. 2015, 22, 1285-1287. [CrossRef] [PubMed]

5. Raices, M.; D'Angelo, M.A. Structure, Maintenance, and Regulation of Nuclear Pore Complexes: The Gatekeepers of the Eukaryotic Genome. Cold Spring Harb. Perspect. Biol. 2021, 13, a040691. [CrossRef] [PubMed]

6. Makarov, A.A.; Padilla-Mejia, N.E.; Field, M.C. Evolution and diversification of the nuclear pore complex. Biochem. Soc. Trans. 2021, BST20200570. [CrossRef]

7. Heinss, N.; Sushkin, M.; Yu, M.; Lemke, E.A. Multifunctionality of F-rich nucleoporins. Biochem. Soc. Trans. 2020, 48, 2603-2614. [CrossRef] [PubMed]

8. Stanley, G.J.; Fassati, A.; Hoogenboom, B.W. Biomechanics of the transport barrier in the nuclear pore complex. Semin. Cell Dev. Biol. 2017, 68, 42-51. [CrossRef] [PubMed]

9. Ding, B.; Sepehrimanesh, M. Nucleocytoplasmic Transport: Regulatory Mechanisms and the Implications in Neurodegeneration. Int. J. Mol. Sci. 2021, 22, 4165. [CrossRef]

10. Kumanski, S.; Viart, B.T.; Kossida, S.; Moriel-Carretero, M. Lipid Droplets Are a Physiological Nucleoporin Reservoir. Cells 2021, 10, 472. [CrossRef]

11. Zhao, Y.G.; Zhang, H. Phase Separation in Membrane Biology: The Interplay between Membrane-Bound Organelles and Membraneless Condensates. Dev. Cell 2020, 55, 30-44. [CrossRef]

12. Mohamed, M.S.; Hazawa, M.; Kobayashi, A.; Guillaud, L.; Watanabe-Nakayama, T.; Nakayama, M.; Wang, H.; Kodera, N.; Oshima, M.; Ando, T.; et al. Spatiotemporally tracking of nano-biofilaments inside the nuclear pore complex core. Biomaterials 2020, 256, 120198. [CrossRef]

13. Mohamed, M.S.; Kobayashi, A.; Taoka, A.; Watanabe-Nakayama, T.; Kikuchi, Y.; Hazawa, M.; Minamoto, T.; Fukumori, Y.; Kodera, N.; Uchihashi, T.; et al. High-Speed Atomic Force Microscopy Reveals Loss of Nuclear Pore Resilience as a Dying Code in Colorectal Cancer Cells. ACS Nano 2017, 11, 5567-5578. [CrossRef]

14. Kalita, J.; Kapinos, L.E.; Lim, R.Y.H. On the asymmetric partitioning of nucleocytoplasmic transport-recent insights and open questions. J. Cell Sci. 2021, 134, jcs240382. [CrossRef] [PubMed]

15. Funasaka, T.; Balan, V.; Raz, A.; Wong, R.W. Nucleoporin Nup98 mediates galectin-3 nuclear-cytoplasmic trafficking. Biochem. Biophys. Res. Commun. 2013, 434, 155-161. [CrossRef]

16. Wong, R.W. Interaction between Rae1 and cohesin subunit SMC1 is required for proper spindle formation. Cell Cycle 2010, 9 , 198-200. [CrossRef] [PubMed]

17. Wong, R.W.; Blobel, G.; Coutavas, E. Rae1 interaction with NuMA is required for bipolar spindle formation. Proc. Natl. Acad. Sci. USA 2006, 103, 19783-19787. [CrossRef] [PubMed]

18. Nakano, H.; Funasaka, T.; Hashizume, C.; Wong, R.W. Nucleoporin translocated promoter region (Tpr) associates with dynein complex, preventing chromosome lagging formation during mitosis. J. Biol. Chem. 2010, 285, 10841-10849. [CrossRef] [PubMed]

19. Kobayashi, A.; Hashizume, C.; Dowaki, T.; Wong, R.W. Therapeutic potential of mitotic interaction between the nucleoporin Tpr and aurora kinase A. Cell Cycle 2015, 14, 1447-1458. [CrossRef] [PubMed]

20. Dewi, F.R.P.; Domoto, T.; Hazawa, M.; Kobayashi, A.; Douwaki, T.; Minamoto, T.; Wong, R.W. Colorectal cancer cells require glycogen synthase kinase-3beta for sustaining mitosis via translocated promoter region (TPR)-dynein interaction. Oncotarget 2018, 9, 13337-13352. [CrossRef]

21. Hashizume, C.; Kobayashi, A.; Wong, R.W. Down-modulation of nucleoporin RanBP2/Nup358 impaired chromosomal alignment and induced mitotic catastrophe. Cell Death Dis. 2013, 4, e854. [CrossRef]

22. Hashizume, C.; Moyori, A.; Kobayashi, A.; Yamakoshi, N.; Endo, A.; Wong, R.W. Nucleoporin Nup62 maintains centrosome homeostasis. Cell Cycle 2013, 12, 3804-3816. [CrossRef]

23. Hartono; Hazawa, M.; Lim, K.S.; Dewi, F.R.P.; Kobayashi, A.; Wong, R.W. Nucleoporin Nup58 localizes to centrosomes and mid-bodies during mitosis. Cell Div. 2019, 14, 7. [CrossRef] 
24. Hashizume, C.; Nakano, H.; Yoshida, K.; Wong, R.W. Characterization of the role of the tumor marker Nup88 in mitosis. Mol. Cancer 2010, 9, 119. [CrossRef] [PubMed]

25. Kutay, U.; Juhlen, R.; Antonin, W. Mitotic disassembly and reassembly of nuclear pore complexes. Trends Cell Biol. 2021. [CrossRef] [PubMed]

26. Nakano, H.; Wang, W.; Hashizume, C.; Funasaka, T.; Sato, H.; Wong, R.W. Unexpected role of nucleoporins in coordination of cell cycle progression. Cell Cycle 2011, 10, 425-433. [CrossRef] [PubMed]

27. Wong, R.W.; Blobel, G. Cohesin subunit SMC1 associates with mitotic microtubules at the spindle pole. Proc. Natl. Acad. Sci. USA 2008, 105, 15441-15445. [CrossRef]

28. Wong, R.W. An update on cohesin function as a 'molecular glue' on chromosomes and spindles. Cell Cycle 2010, 9, 1754-1758. [CrossRef]

29. Yi, F.; Zhang, Y.; Wang, Z.; Wang, Z.; Li, Z.; Zhou, T.; Xu, H.; Liu, J.; Jiang, B.; Li, X.; et al. The deacetylation-phosphorylation regulation of SIRT2-SMC1A axis as a mechanism of antimitotic catastrophe in early tumorigenesis. Sci. Adv. 2021, 7, eabe5518. [CrossRef]

30. Kobayashi, Y.; Masuda, T.; Fujii, A.; Shimizu, D.; Sato, K.; Kitagawa, A.; Tobo, T.; Ozato, Y.; Saito, H.; Kuramitsu, S.; et al. Mitotic checkpoint regulator RAE1 promotes tumor growth in colorectal cancer. Cancer Sci. 2021, 112, 3173-3189. [CrossRef]

31. Hazawa, M.; Lin, D.C.; Kobayashi, A.; Jiang, Y.Y.; Xu, L.; Dewi, F.R.P.; Mohamed, M.S.; Hartono; Nakada, M.; Meguro-Horike, M.; et al. ROCK-dependent phosphorylation of NUP62 regulates p63 nuclear transport and squamous cell carcinoma proliferation. EMBO Rep. 2018, 19, 73-88. [CrossRef]

32. Hazawa, M.; Sakai, K.; Kobayashi, A.; Yoshino, H.; Iga, Y.; Iwashima, Y.; Lim, K.S.; Chih-Cheng Voon, D.; Jiang, Y.Y.; Horike, S.I.; et al. Disease-specific alteration of karyopherin-alpha subtype establishes feed-forward oncogenic signaling in head and neck squamous cell carcinoma. Oncogene 2020, 39, 2212-2223. [CrossRef]

33. Lim, K.S.; Wong, R.W. Targeting Nucleoporin POM121-Importin beta Axis in Prostate Cancer. Cell Chem. Biol. 2018, 25, 1056-1058. [CrossRef]

34. Funasaka, T.; Wong, R.W. The role of nuclear pore complex in tumor microenvironment and metastasis. Cancer Metastasis Rev. 2011, 30, 239-251. [CrossRef] [PubMed]

35. Funasaka, T.; Nakano, H.; Wu, Y.; Hashizume, C.; Gu, L.; Nakamura, T.; Wang, W.; Zhou, P.; Moore, M.A.; Sato, H.; et al. RNA export factor RAE1 contributes to NUP98-HOXA9-mediated leukemogenesis. Cell Cycle 2011, 10, 1456-1467. [CrossRef] [PubMed]

36. Mendes, A.; Juhlen, R.; Bousbata, S.; Fahrenkrog, B. Disclosing the Interactome of Leukemogenic NUP98-HOXA9 and SETNUP214 Fusion Proteins Using a Proteomic Approach. Cells 2020, 9, 1666. [CrossRef] [PubMed]

37. Funasaka, T.; Tsuka, E.; Wong, R.W. Regulation of autophagy by nucleoporin Tpr. Sci. Rep. 2012, 2, 878. [CrossRef]

38. Dewi, F.R.P.; Jiapaer, S.; Kobayashi, A.; Hazawa, M.; Ikliptikawati, D.K.; Hartono; Sabit, H.; Nakada, M.; Wong, R.W. Nucleoporin TPR (translocated promoter region, nuclear basket protein) upregulation alters MTOR-HSF1 trails and suppresses autophagy induction in ependymoma. Autophagy 2021, 17, 1001-1012. [CrossRef]

39. Uhlirova, J.; Sebestova, L.; Fiser, K.; Sieger, T.; Fiserova, J.; Hozak, P. Nucleoporin TPR Affects C2C12 Myogenic Differentiation via Regulation of Myh4 Expression. Cells 2021, 10, 1271. [CrossRef]

40. Lee, C.W.; Wilfling, F.; Ronchi, P.; Allegretti, M.; Mosalaganti, S.; Jentsch, S.; Beck, M.; Pfander, B. Selective autophagy degrades nuclear pore complexes. Nat. Cell Biol. 2020, 22, 159-166. [CrossRef]

41. Tomioka, Y.; Kotani, T.; Kirisako, H.; Oikawa, Y.; Kimura, Y.; Hirano, H.; Ohsumi, Y.; Nakatogawa, H. TORC1 inactivation stimulates autophagy of nucleoporin and nuclear pore complexes. J. Cell Biol. 2020, 219, e201910063. [CrossRef]

42. Yang, X.; Li, X.; Gu, Q.; Li, Q.; Cui, Z. Nucleoporin 62-Like Protein is Required for the Development of Pharyngeal Arches through Regulation of Wnt/beta-Catenin Signaling and Apoptotic Homeostasis in Zebrafish. Cells 2019, 8, 1038. [CrossRef] [PubMed]

43. Okazaki, R.; Yamazoe, K.; Inoue, Y.H. Nuclear Export of Cyclin B Mediated by the Nup62 Complex Is Required for Meiotic Initiation in Drosophila Males. Cells 2020, 9, 270. [CrossRef] [PubMed]

44. Wong, R.W.; Mamede, J.I.; Hope, T.J. Impact of Nucleoporin-Mediated Chromatin Localization and Nuclear Architecture on HIV Integration Site Selection. J. Virol. 2015, 89, 9702-9705. [CrossRef]

45. Blanco-Rodriguez, G.; Di Nunzio, F. The Viral Capsid: A Master Key to Access the Host Nucleus. Viruses 2021, 13, 1178. [CrossRef] [PubMed]

46. Shukla, E.; Chauhan, R. Host-HIV-1 Interactome: A Quest for Novel Therapeutic Intervention. Cells 2019, 8, 1155. [CrossRef] [PubMed]

47. Sajidah, E.S.; Lim, K.; Wong, R.W. How SARS-CoV-2 and Other Viruses Build an Invasion Route to Hijack the Host Nucleocytoplasmic Trafficking System. Cells 2021, 10, 1424. [CrossRef] [PubMed]

48. Kato, K.; Ikliptikawati, D.K.; Kobayashi, A.; Kondo, H.; Lim, K.; Hazawa, M.; Wong, R.W. Overexpression of SARS-CoV-2 protein ORF6 dislocates RAE1 and NUP98 from the nuclear pore complex. Biochem. Biophys. Res. Commun. 2021, 536, 59-66. [CrossRef] [PubMed]

49. Miorin, L.; Kehrer, T.; Sanchez-Aparicio, M.T.; Zhang, K.; Cohen, P.; Patel, R.S.; Cupic, A.; Makio, T.; Mei, M.; Moreno, E.; et al. SARS-CoV-2 Orf6 hijacks Nup98 to block STAT nuclear import and antagonize interferon signaling. Proc. Natl. Acad. Sci. USA 2020, 117, 28344-28354. [CrossRef] [PubMed] 
50. Corbeil, D.; Santos, M.F.; Karbanova, J.; Kurth, T.; Rappa, G.; Lorico, A. Uptake and Fate of Extracellular Membrane Vesicles: Nucleoplasmic Reticulum-Associated Late Endosomes as a New Gate to Intercellular Communication. Cells 2020, 9, 1931. [CrossRef] [PubMed]

51. Nishide, G.; Lim, K.; Mohamed, M.S.; Kobayashi, A.; Hazawa, M.; Watanabe-Nakayama, T.; Kodera, N.; Ando, T.; Wong, R.W. High-Speed Atomic Force Microscopy Reveals Spatiotemporal Dynamics of Histone Protein H2A Involution by DNA Inchworming. J. Phys. Chem. Lett. 2021, 12, 3837-3846. [CrossRef]

52. Hirano, Y.; Asakawa, H.; Sakuno, T.; Haraguchi, T.; Hiraoka, Y. Nuclear Envelope Proteins Modulating the Heterochromatin Formation and Functions in Fission Yeast. Cells 2020, 9, 1908. [CrossRef]

53. Kuhn, T.M.; Capelson, M. Nuclear Pore Proteins in Regulation of Chromatin State. Cells 2019, 8, 1414. [CrossRef] [PubMed]

54. Ando, T. High-speed atomic force microscopy. Curr. Opin. Chem. Biol. 2019, 51, 105-112. [CrossRef]

55. Tunyasuvunakool, K.; Adler, J.; Wu, Z.; Green, T.; Zielinski, M.; Zidek, A.; Bridgland, A.; Cowie, A.; Meyer, C.; Laydon, A.; et al. Highly accurate protein structure prediction for the human proteome. Nature 2021. [CrossRef]

56. Jumper, J.; Evans, R.; Pritzel, A.; Green, T.; Figurnov, M.; Ronneberger, O.; Tunyasuvunakool, K.; Bates, R.; Zidek, A.; Potapenko, A.; et al. Highly accurate protein structure prediction with AlphaFold. Nature 2021. [CrossRef] [PubMed]

57. Shinkai, Y.; Kuramochi, M.; Miyafusa, T. New Family Members of FG Repeat Proteins and Their Unexplored Roles During Phase Separation. Front. Cell Dev. Biol. 2021, 9, 708702. [CrossRef] [PubMed]

58. Blobel, G. Gene gating: A hypothesis. Proc. Natl. Acad. Sci. USA 1985, 82, 8527-8529. [CrossRef] 